\title{
Rapid colonization of new habitats in the Wadden Sea by the ovoviviparous Littorina saxatilis (Olivi)
}

\author{
U. Wilhelmsen
}

\author{
Research Centre Terramare; Schleusenstrasse 1, 26382 Wilhelmshaven, Germany
}

\begin{abstract}
The intertidal periwinkle Littorina saxalilis completely lacks larval dispersal and adult vagility is low. Although this suggests a low dispersal rate, L. saxatilis is frequently found in recently established habitats "exotic" to the Wadden Sea. Populations occur on man-made structures like dikes, breakwaters and groynes, some of which are not older than several years. Furthermore, L. saxatilis is found on marsh grass Spartina anglica, introduced to the Wadden Sea in the 1920s and 1930s, as well as on mats of green macrodgae, which have become an abundant feature on the tidal flats since the late 1970s. Seagrass beds are likely to be the original habitat of L. saxatilis in the Wadden Sea. Since seagrass populations have dramatically declined over the last decades, colonization of new habitat types enabled $L$. saxatilis to maintain its Wadden Sea populations despite a changing environment. Colonizers can reach new habitats by means of passive transport, especially by rafting on macrophytes and by aerial dispersal attached to birds. In the Wadden Sea, the ovoviviparously reproducing L. saxatilis has demonstrated its ability to successfully found new populations with only a few individuals. No reduction of genetic variablility (founder effect) was observed in recently established populations.
\end{abstract}

\section{INTRODUCTION}

Littorina saxatilis (Olivi) is a common member of rocky shore macrofaunas. It is widely distributed along Atlantic coasts and occurs in the upper intertidal zone and in the littoral fringe of both sheltered and exposed rocky shores (Fretter \& Graham, 1980). Though being a hard bottom dweller, L. saxatilis is also found in the Wadden Sea, a shallow tidal area along the Dutch, German and Danish North Sea coast, dominated by soft sediments. In the Wadden Sea L. saxatilis is restricted to patches of firm substrata, i.e. man-made structures, and macrophytes which occur scattered in unstable sediment flats. Many of these habitats first appeared during the twentieth century.

Eggs and embryos of $L$. saxatilis develop in a brood pouch of the female and are released as shelled, benthic juveniles. Adult vagility is in the range of a few meters per 3 months (Janson, 1983). Although this very limited capacity of active dispersal suggests that $L$. saxatilis is a poor disperser, occasionally long-distance migration takes place (Johannesson, 1988). L. saxatilis was found to successfully invade new territories (Knight et al., 1987) and colonize new habitats (Johannesson \& Warmoes, 1990; Johannesson \& Johannesson, 1995). Passive transport was suggested to be an effective dispersal mechanism for this ovoviviparous species, with a small founder group being sufficient to establish a new population (Janson, 1987).

Biologische Anstalt Helgoland, Hamburg 


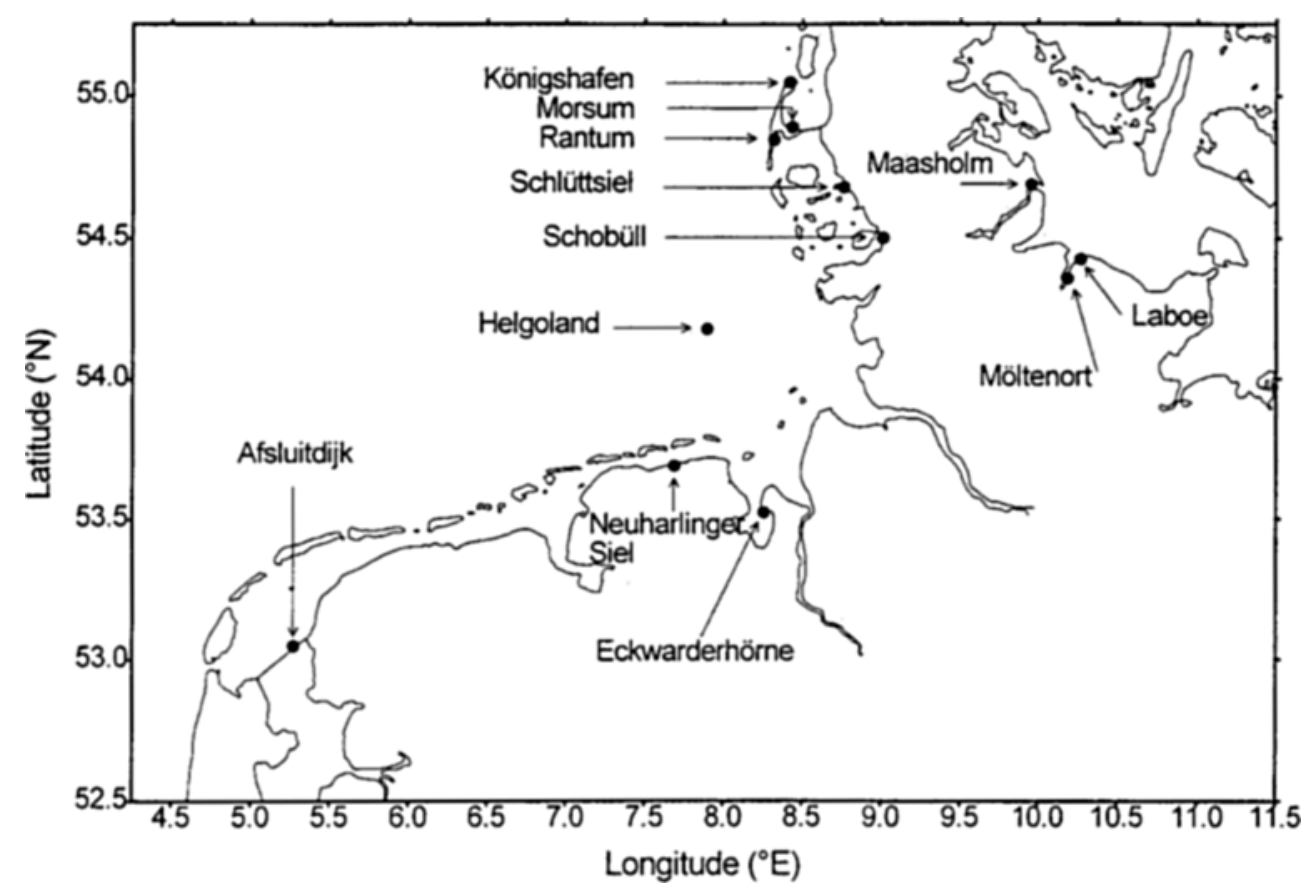

Fig. 1. Study sites along the shores of the southern North Sea and the western Baltic. Königshafen, Morsum and Rantum belong to the island of Sylt

Mayr's (1963) "founder principle" predicts reduced genetic variation and increased homozygosity in a population founded by a small number of individuals. Founder effects have been described for two introduced South African populations of $L$. saxatilis (Knight et al., 1987), but not for newly established L. saxatilis populations of the Belgian coast (Johannesson \& Warmoes, 1990) and the Swedish West coast (Janson, 1987).

This article focuses on the natural and anthropogenically induced changes of Wadden Sea habitats relevant to L. saxatilis. Present-day habitats of $L$. saxatilis in the Wadden Sea are described and colonization of new habitats by this ovoviviparous species with limited dispersal capacity is discussed. Data of genetic variability within populations of $L$. saxatilis are compared for the occurrence of founder effects in recently established Wadden Sea populations. A detailed description of population genetics is given elsewhere (Wilhelmsen, 1998). Furthermore, habitat spectrum and colonization potential of the ovoviviparous $L$. saxatilis are compared with other Wadden Sea littorinids, i.e. the oviparous Littorina fabalis Turton (= L. mariae Sacchi \& Rastelli; for synonomy see Reid, 1996) and Littorina littorea (L.) with planktonic eggs and larvae.

Species with planktonic larvae are assumed to be more superior colonizers than species with non-planktonic larvae when sessile or less mobile adults occupy temporally unpredictable habitats (Gadgil, 1971). This study gives an example of a species that, despite of its non-planktonic development and very restricted capacity of active 
dispersal, has colonized recently established "exotic" Wadden Sea habitats and has persisted under dynamic and changing habitat conditions.

\section{MATERIALS AND METHODS}

A total of 26 populations of $L$. suxatilis was sampled, 15 from the Wadden Sea, 6 from the rocky island Helgoland and 5 from the western Baltic (Fig. 1). A minimum of 50 specimens per population were collected by hand, transported alive to the laboratory and stored at $-70^{\circ} \mathrm{C}$ until electrophoresis. 19 enzyme loci were screened in samples of 30 or more individuals per population, applying standard methods of starch gel electrophoresis (Harris \& Hopkinson, 1976; Richardson et al., 1986). Stains were prepared for aconitase, arginine kinase, aspartate aminotransferase, cytosol aminopeptidase, esterase, glucose-6-phosphate isomerase, malate dehydrogenase, mannose-6-phosphate isomerase, peptidase, phosphoglucomutase, and purine-rucleoside phosphorylase. A detailed description of methods is given in Wilhelmsen (1998). Data analysis was performed using the BIOSYS-1.7 software package (Swofford \& Selander, 1981).

In the northern part of the Wadden Sea, near the island of Sylt, the occurrence of L. saxatilis and other littorinids was recorded in different types of habitats and densities of snails were determined for areas of $1 \mathrm{~m}^{2}$.

\section{RESULTS}

Habitats of L. saxatilis in the Wadden Sea

The Wadden Sea coast has no natural rocky intertidal sites and rocky shore species are restricted to patches of suitable firm substrata. L. saxatilis occurs on man-made structures and on several macrophytes.

Habitat changes relevant to $L$. saxatilis on the tidal flats of Königshafen are shown in Fig. 2. Seventy years ago L. saxatilis was only present in the extensive seagrass beds in Königshafen (Wohlenberg, 1937), which were mapped by Nienburg (1927). During the following decades, the extent of seagrass beds declined but new habitats appeared. Nowadays, populations of $L$. saxatilis are frequently found on a dike built in 1938 , on patches of the introduced marsh grass Spartina anglica and on dense mats of green macroalgae (Enteromorpha spp.) which first appeared in 1979 on the tidal flats of Königshafen (Reise, 1983).

\section{Habitat spectra of Littorina spp.}

In Table 1 habitat spectra of $L$. saxatilis and the two other littorinids occurring in the North Frisian Wadden Sea are compared. The planktonic developer L. littorea also colonized new Wadden Sea habitats (artificial rock and algal mats), so that populations of $L$. Hittorea and $L$. saxatilis occurred sympatrically, but it was not found on the introduced marsh grass $S$. anglica. The flat periwinkle $L$. fabalis was restricted to Fucus sp. forma mytili growing on intertidal mussel beds in the Wadden Sea.

Especially $L$. littorea is able to colonize a variety of hard-and soft-bottom habitats in the Wadden Sea, reaching particularly high abundances (several hundreds per 

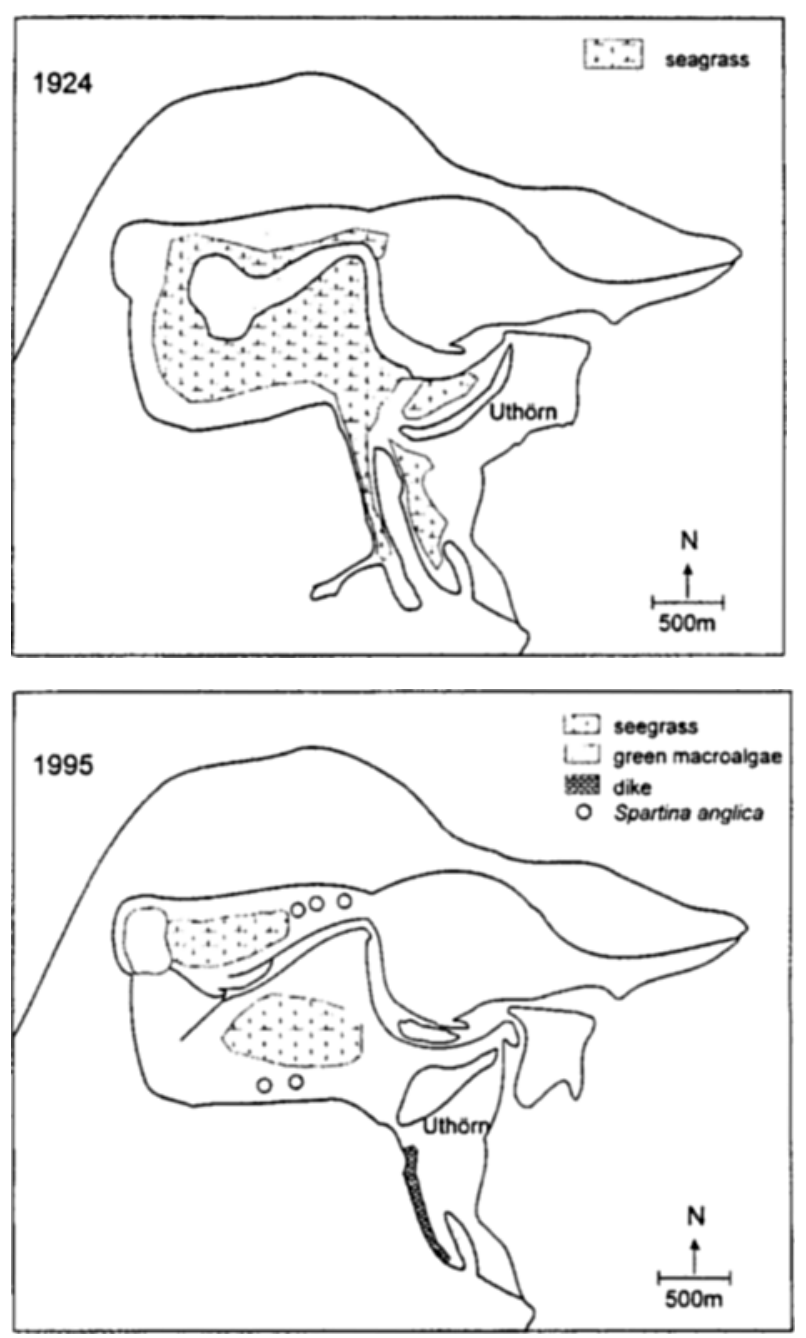

Fig. 2. Habitat changes relevant to L. saxatilis on tidal flats of Königshafen at the northern tip of the island of Sylt. 1924: modified from Nienburg (1927); 1995: this study

square meter) on hard substrata (artificial rocks and mussel beds) whereas densities of both $L$. saxatilis and $L$. fabalis in their Wadden Sea habitats are in the range of several tens per square meter.

Genetic variability within populations of L. saxatilis

The genetic variability within populations of $L$. saxatilis is summarized in Table 2 [allele frequencies are given in Wilhelmsen (1998)]. None of the three parameters of genetic variability within populations [mean number of alleles per locus (A), percentage of polymorphic loci $\left(\mathrm{P}_{95}\right)$, expected heterozygosity $\left.\left(\mathrm{H}_{\mathrm{L}}\right)\right]$ indicates a reduced variability of 
Table 1. Population densities of Littorina spp. in Wadden Sea habitats, indicated as - (absent), $+/-\left(\right.$ less than 5 individuals $\left.\mathrm{m}^{-2}\right),+\left(10-100 \text { individuals } \mathrm{m}^{-2}\right)_{1}++\left(100-1000\right.$ individuals $\left.\mathrm{m}^{-2}\right)$

\begin{tabular}{|lccc|}
\hline Habitats in the Wadden Sea & L. saxatilis & L. Iittorea & L. fabalis \\
\hline Seagrass beds & + & + & - \\
Artificial rock* & + & ++ & - \\
Green algal mats * & + & + & - \\
Spartina anglica & + & - & - \\
Bare sediment & - & ++- & - \\
Mussel beds & - & ++ & + \\
Mussel beds with fucoid cover & - & & \\
new Wadden Sea habitats & & & \\
\hline
\end{tabular}

Table 2. Summary statistics of genetic variability in 26 populations of $L$. saxatilis for 19 loci. $\mathrm{A}=$ mean number of alleles per locus; $P_{! n}=$ percentage of loci polymorphic la locus is considered polymorphic if the frequency of the most common allele does not exceed 0.95 ); $\mathrm{H}_{{ }^{\prime} \times \mathrm{xp}}$ = average heterozygosity per locus per population (Hardy-Weinberg expected)

\begin{tabular}{|c|c|c|c|c|}
\hline Population (location see Fig. 1.) & Habitat & A & $P_{15}$ & $H_{e x p}$ \\
\hline Wadden Sea 1, Eckwarderhöne & Dike* & 2.1 & 52.6 & 0.193 \\
\hline Wadden Sea 2, Eckwarderhörne & Dike $^{*}$ & 2.0 & 52.6 & 0.185 \\
\hline Wadden Sea 3, Neuharlinger Siel & Dike ${ }^{*}$ & 2.1 & 52.6 & 0.255 \\
\hline Wadden Sea 4, Afsluitdijk & Dike & 2.0 & 47.4 & 0.245 \\
\hline Wadden Sea 5, Königshafen & Dike & 2.3 & 57.9 & 0.216 \\
\hline Wadden Sea 6, Königshafen & Dike & 1.9 & 47.4 & 0.194 \\
\hline Wadden Sea 7 , Königshafen & Green algal mats & 2.1 & 47.4 & 0.208 \\
\hline Wadden Sea 8, Königshafen & Green algal mats & 2.1 & 52.6 & 0.206 \\
\hline Wadden Sea 9, Morsum & Groyne & 2.1 & 47.4 & 0.197 \\
\hline Wadden Sea 10, Morsum & Groyne & 2.1 & 57.9 & 0.201 \\
\hline Wadden Sea 11, Morsum & Spartina & 1.9 & 52.6 & 0.204 \\
\hline Wadden Sea 12, Morsum & Spartina & 2.1 & 57.9 & 0.212 \\
\hline Wadden Sea 13, Rantum & Spartina & 2.1 & 57.9 & 0.209 \\
\hline Wadden Sea 14, Schobüll & Spartina & 2.1 & 57.9 & 0.224 \\
\hline Wadden Sea 15 , Schlüttsiel & Groyne & 2.2 & 57.9 & 0.206 \\
\hline Helgoland 1 & Rocky shore & 2.1 & 52.6 & 0.214 \\
\hline Helgoland 2 & Rocky shore & 1.9 & 57.9 & 0.224 \\
\hline Helgoland 3 & Rocky shore & 1.9 & 52.6 & 0.223 \\
\hline Helgoland 4 & Rocky shore & 1.8 & 52.6 & 0.222 \\
\hline Helgoland 5 & Tetrapods & 1.9 & 57.9 & 0.232 \\
\hline Helgoland 6 & Tetrapods & 1.9 & 52.6 & 0.224 \\
\hline Baltic Sea 1, Möltenort & Boulder shore & 2.3 & 52.6 & 0.234 \\
\hline Baltic Sea 2, Laboe & Boulder shore & 2.0 & 52.6 & 0.224 \\
\hline Baltic Sea 3, Laboe & Boulder shore & 1.9 & 57.9 & 0.231 \\
\hline Baltic Sea 4, Laboe & Boulder shore & 1.9 & 52.6 & 0.235 \\
\hline Baltic Sea 5, Maasholm & Fucus vesiculosus & 2.3 & 52.6 & 0.215 \\
\hline
\end{tabular}


recently founded populations as predicted by the "founder principle". Newly established populations of $L$. saxatilis occurring on very recent (after 1990) dikes show both low (Eckwarderhörne) and surprisingly high (Neuharlinger Siel) levels of heterozygosity $\left(\mathrm{H}_{\mathrm{L}}\right)$. Thus, in these new populations no founder effects are observed a few years after colonization of the dikes took place.

Although there is an extensive overlap in the range of $\mathrm{H}_{\mathrm{L}}$, the Wadden Sea populations of $L$. saxatilis tend to be somewhat less variable (mean $\mathrm{H}_{\mathrm{L}}=0.210$, range $=$ $0.185-0.255$ ) than populations from the rocky island of Helgoland (mean $\mathrm{H}_{\mathrm{L}}=0.223$, range $=0.214-0.232$ ) and from the western Baltic Sea (mean $H_{L}=0.228$, range $=$ 0.215-0.235). Whereas many Wadden Sea habitats of L. saxatilis appeared during recent years or decades, the rocky intertidal of Helgoland and the boulder shores of the western Baltic are much older.

\section{DISCUSSION}

\section{Ecological history of habitats}

Similar habitat changes as documented for the tidal flats of Königshafen also took place in other parts of the Wadden Sea:

"Artificial rocks" have appeared all along the coasts of the North Sed. Although people started building dikes in the Wadden Sea area about 1000 years ago (Bantelmann, 1966; Wolff, 1992a), the modern coastal architecture with large sea dikes, causeways, harbors, breakwaters and groynes along the entire coastline was established during the last century. "Artificial rocks" provide suitable habitats for many rocky shore species, of which L. saxatilis is a common representative (Michaelis, 1987; Johannesson \& Warmoes, 1990; de Boer \& de Bruyne, 1991, this study).

The marsh grass Spartina anglica was introduced to the Wadden Sea area in the 1920s and 1930s for the purpose of land reclamation (König, 1949; Pedersen, 1983) and is now widely distributed, especially along the mainland coast (Dijkema, 1983). Whereas L. saxatilis frequently occurs on Spartina stands, it is not found on saltwort (Salicornia europaea, personal observations), which is the original macrophyte in the transition zone between tidal flats and lower saltmarsh. Also, Wohlenberg (1937) and Linke (1939) documented the frequent occurrence of L. saxatilis in seagrass beds, but not on Salicornia stands. Therefore it seems likely that L. saxatilis was not abundant in the lower saltmarsh before Spartina anglica was introduced into the Wadden Sea.

Dense mats of green macroalgae have appeared since the 1970 s on the tidal flats (Reise, 1983; Reise et al., 1989) and generally develop through the excessive growth of several green alga species. In the German Wadden Sea these mats are mostly formed by the genus Enteromorpha (Reise \& Siebert, 1994; Kolbe et al., 1995), whereas in the Dutch part of the Wadden Sea Ulva species predominate (de Jonge et al., 1993). Seagrass beds in the upper intertidal are frequently overgrown by green macroalgae (Bock \& Brodowski, 1993).

Seagrass beds (Zostera marina and Z. noltii) are assumed to be the original Wadden Sea habitats of $L$. saxatilis. This species was (Wohlenberg, 1937; Linke, 1939) and still is (Reise, 1985; Hellwig-Armonies, 1988) a common inhabitant of the seagrass community. 
During the twentieth century seagrass beds have dramatically declined in several regions of the Wadden Sea (Michaelis, 1987; Philippart et al., 1992; Reise, 1994). They are now listed as "heavily endangered biotopes" in the current Red List of the Wadden Sea area (Ssymank \& Dankers, 1996). Despite this loss of habitat L. saxatilis has been able to maintain its Wadden Sea populations by successfully colonizing new habitat types (artificial rock, Spartina anglica, green algae mats). In contrast, some other gastropods (Rissoa membranacea, Lacuna vincta, Nassarius reticulatus) seem to have disappeared together with the seagrass (Wolff, 1992b; Reise, 1994).

\section{Colonization of habitats}

The ovoviviparous $L$. saxatilis has a very limited capacity of active dispersal, but passive transport can be important (Janson, 1987; Johannesson, 1988; Johannesson \& Warmoes, 1990). Especially in the Wadden Sea, passive transport seems likely, because macrophytes represent strongly utilized habitat structures for L. saxatilis, whereas the rocky shore populations live on stable and permanent hard subtrata. Seagrass, green algae and Spartina undergo seasonal declines. Mats of green algae are dispersed by strong storms (Reise, 1983) and seagrass loses its leaves in autumn. Therefore, rafting on plant material can be an important mechanism for dispersal of $L$. saxatilis in the Wadden Sea. Furthermore, ducks and geese (Anas penelope, Branta bernicla) use green algal mats (Nicholls et al., 1981) as well as seagrass (Madsen, 1988) as food sources and consume considerable amounts of seagrass biomass (Asmus et al., 1998). Therefore, aerial dispersal attached to birds (Malone, 1965) can be another effective way of transport.

Single drifting individuals of $L$. saxatilis can successfully found a new population because of their reproductive pattern: a founder group of the ovoviviparous $L$. saxatilis may consist of only one fertilized female, which is able to store sperm and give birth to offspring over a period of more than 1 year in the absence of males (Janson, 1987). Annual reproductive capacity is between 50 and 500 juveniles per female, depending on female size (Roberts $\&$ Hughes, 1980) with reproduction occurring more or less continually throughout the year (Ross \& Berry, 1991) and juveniles settling in the direct vicinity of the mother.

A small group of $L$. saxatilis populating a formerly non-utilized habitat can increase rapidly in population size (Johannesson \& Johannesson, 1995). Rapid population growth following a bottleneck of reduced population density can largely prevent a drop in the heterozygosity of a population (Chakraborty \& Nei, 1977). As argued by Janson (1987) this may be one reason for the absence of founder effects in newly established populations of L. saxatilis. It may explain the lack of correlation between heterozygosity of Wadden Sea populations and habitat age (see Table 2). Population densities of L. saxatilis on the new dikes (Eckwarderhörne, Neuharlingersiel) were in the same order of magnitude (several tens per square meter) as in other Wadden Sea sites (personal observations) indicating that population density had already been restored after the bottleneck. Comparing L. saxatilis populations from Belgian breakwaters, Johannesson \& Warmoes (1990) also found no correlation between heterozygosity and habitat age. 


\section{Population dynamics}

The colonization potential of $L$. saxatilis is suggested to be a key factor for its persistence under the dynamic and changing habitat conditions in the Wadden Sea. Local populations may become extinct if patches of green algae, seagrass and Spartina decline seasonally or if anthropogenic structures such as dikes, groynes and breakwaters are renewed. However, local extinction can be counterbalanced by the foundation of new populations. Only small founder groups (e.g. single drifting individuals) are necessary in this process and rafting on plant material as well as aerial dispersal of individuals is likely to occur in the Wadden Sea. From a metapopulation perspective (Levins, 1970; Hanski \& Gilpin, 1991), the turnover of local populations, living in discrete habitat patches, is high, but the metapopulation, a system of local populations connected by dispersing individuals, can persist despite the changing and dynamic habitat conditions of the Wadden Sea (Fig. 3). In contrast, on rocky shores metapopulation dynamics are less likely to occur, because L. saxatilis lives on stable and uniformly suitable hard substrata.

\section{Colonization potential of the three species}

Whereas the ovoviviparous $L$. saxatilis apparently is a good colonizer and copes with habitat changes in the Wadden Sea, the oviparous flat periwinkle L. fabalis seems to be far less successful. Being closely linked with its fucoid host algae (Williams, 1996), L. fabalis has failed to colonize the new Wadden Sea habitats (a possible exception are large sea dikes with fucoid cover). It is threatened by habitat loss due to the decline of mussel beds and the associated Fucus sp. forma mytili in several parts of the Wadden Sea (Obert \& Michaelis, 1991; de Jonge et al., 1993). Colonization potential of the oviparous $L$. fabalis is suggested to be lower than that of the ovoviviparous $L$. saxatilis because egg masses embedded in jelly are less tolerant to desiccation, high temperatures and salinity stress than brooded embryos (Hughes, 1995) and suffer high mortality from predation (Gallardo \& Götting, 1985). Therefore rafting egg masses are less

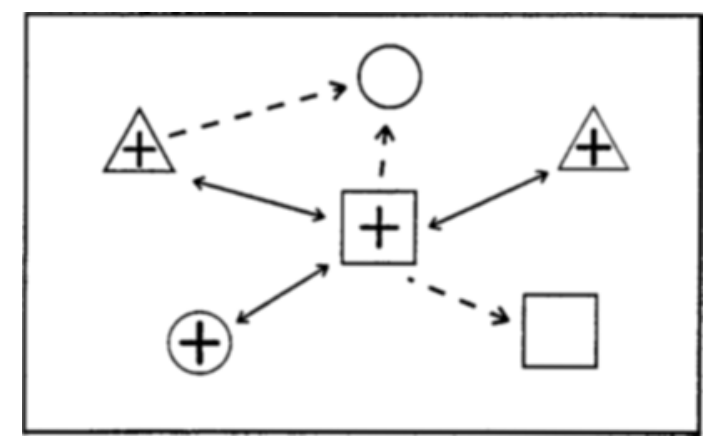

Fig. 3. Metapopulation dynamics suggested for $L$. saxatilis in the Wadden Sea. Local populations (crosses) occur in different types of discrete, ephemeral habitat patches (as indicated by various symbols). Local populations are connected by single drifting individuals which also colonize empty habitats 
likely to survive and found a new population than a shelled adult female with embryos in a brood pouch. Furthermore, $L$. fabalis has a seasonal reproduction pattern (Williams, 1996), whereas L. saxatilis reproduces continually throughout the year (Ross \& Berry, 1991).

The planktonic developer $L$. Littorea is a good disperser and a new population can arise if a large number of larvae or adults reach the same site (Johannesson, 1988). In the Wadden Sea this is very likely, because different types of new and original Wadden Sea habitats are populated (see Table 1) and population densities can be very high, especially on artificial rocks and mussel beds (Albrecht \& Reise, 1994; Wilhelmsen \& Reise, 1994). Because the various already populated habitats can function as sources, colonization potential of L. littorea is assumed to be high in the Wadden Sea, enabling this species to persist under the dynamic and changing habitat conditions.

\section{CONCLUSIONS}

The ovoviviparous L. saxatilis has successfully colonized new habitats in the Wadden Sea. Colonizers can be transported by rafting on macrophytes and by aerial dispersal attached to birds. Few individuals can found a new population, which can expand rapidly. No founder effects (reduced genetic variability) were observed in recently established populations. The colonization potential of $L$. saxatilis plays an important role in maintaining its Wadden Sea populations under the changing and dynamic habitat conditions. In contrast, rocky shore habitats of L. saxatilis are comparatively stable and local populations are more permanent. L. littorea as a species with planktonic development also colonized new Wadden Sea habitats, reaching high densities on artificial rocks, whereas the oviparous L. fabalis was restricted to fucoid-covered mussel beds and may be threatened by habitat loss.

\section{LITERATURE CITED}

Albrecht, A. \& Reise, K., 1994. Effects of Fucus vesiculosus covering intertidal mussel beds in the Wadden Sea. - Helgoländer Meeresunters. 48, 243-256.

Asmus, H., Lackschewitz, D., Asmus, R., Scheiffarth, G., Nehls, G. \& Hermann, J.P., 1998. Transporte im Nahrungsnetz eulitoraler Wattflächen des Sylt-Rømø Wattenmeeres. In: Ökosystem Wattenmeer: Austausch, Transport und Stoffumwandlungsprozesse. Ed. by C. Gätje \& K. Reise. Springer, Berlin Heidelberg New York, 393-420.

Bantelmann, A., 1966. Die Landschaftsentwicklung an der schleswig-holsteinischen Westküste, dargestellt am Beispiel Nordfrieslands. - Küste 14, 5-95.

Bock, H. \& Brodowski, A., 1993. Seegras- und Grünalgenbestände im Nordfriesischen Wattenmeer unter besonderer Berücksichtigung ökologischer Faktoren. Thesis, University of Münster, 185 pp.

Boer, T. de \& Bruyne, R. de, 1991. Schelpen van de Friese Waddeneilanden. Dr. W. Backhuys / U.B.S., Oegstgeest, The Netherlands, 300 pp.

Chakraborty, R. \& Nei, M., 1977. Bottleneck effects on average heterozygosity and genetic distance with the stepwise mutation model, - Evolution 31, 347-356.

Dijkema, K., 1983. Outline of landscape and vegetation types. - Rep. Wadden Sea Working Group 9. 116-133.

Fretter, V. \& Graham, A., 1980. The prosobranch molluscs of Britain and Denmark. Part 5 - marine Littorinacea. - J. Moll. Stud. Suppl. 7. 
Gadgil, M., 1971. Dispersal: population consequences and evolution. - Ecology 52, 253-261.

Gallardo, C. \& Götting, K., 1985. Reproduktionsbiologische Untersuchungen an drei LittorinaArten der südlichen Nordsee. - Helgoländer Meeresunters. 39, 165-186.

Hanski, I. \& Gilpin, M., 1991. Metapopulation dynamics: brief history and conceptual domain.Biol. J. Linn. Soc. 42, 3-16.

Harris, H. \& Hopkinson, D., 1976. Handbook of enzyme electrophoresis in human genetics. NorthHolland, Amsterdam.

Hellwig-Armonies, M., 1988. Mobile epifauna on Zostera marina, and infauna of its inflorescences. - Helgoländer Meeresunters. 42, 329-337.

Hughes, R., 1995. Resource allocation, demography and the radiation of life histories in rough periwinkles (Gastropoda). - Hydrobiologia 309, 1-14

Janson, K., 1983. Selection and migration in two distinct phenotypes of Littorina saxatilis in Sweden. - Oecologia 59, 58-61

Janson, K., 1987. Genetic drift in small and recently founded populations of the marine snail Litlorina saxatilis. - Heredity 58, 31-37.

Johannesson, K., 1988. The paradox of Rockall: why is a brooding gastropod (Littorina saxatilis) more widespread than one having a planktonic larval dispersal stage (L. litlorea)? - Mar. Biol. 99, 507-513.

Johannesson, K. \& Johannesson, B., 1995. Dispersal and population expansion in a direct developing marine snail (Littorina saxatilis) following a severe population bottleneck. - Hydrobiologid 309, 173-180.

Johannesson, K. \& Warmoes, T., 1990. Rapid colonization of Belgian breakwaters by the direct developer, Littorina saxatilis (Olivi) (Prosobranchid, Mollusca). - Hydrobiologia 193, 99-108.

Jonge, V. de, Essink, K. \& Boddeke, R., 1993. The Dutch Wadden Sea: a changed ecosystem. - Hydrobiologia 265, 45-71.

Knight, A., Hughes, R. \& Ward, R., 1987. A striking example of the founder effect in the mollusc Littorina saxatilis. - Biol. J. Linn. Soc. 32, 417-426.

Kolbe, K., Kaminski, E., Michaelis, H., Obert, B. \& Rahmel J., 1995. Macroalyal mass development in the Wadden Sea: first experiences with a monitoring system. - Helgoländer Meeresunters. $49,519-528$.

König, D., 1949. Spartina townsendii an der Westküste von Schleswig-Holstein. - Planta 36, 34-50.

Levins, R., 1970. Extinction. In: Some mathematical questions in biology. Ed. by M. Gerstenhaber. 2. American Mathematical Society, Providence, 77-107.

Linke, O., 1939. Die Biota des Jadebusenwatts. - Helgoländer Wiss. Meeresunters. 1, 201-348.

Madsen, J., 1988. Autumn feeding ecology of herbivorous wildfowl in the Danish Wadden Sed, and impact of food supplies and shooting on movements. - Dan. Rev. Game Biol. 13(4), 1-32.

Malone, C.R., 1965. Killdeer (Charadrius vociferus Linnaeus) as a means of dispersal for aquatic gastropods. - Ecology 46, 551-552.

Mayr, E., 1963. Animal species and evolution. Harvard University Press, Cambridge, 797 pp.

Michaelis, H., 1987. Bestandsaufnahme des eulitoralen Makrobenthos im Jadebusen in Verbindung mit einer Luftbild-Analyse. - Jahresber. Forschst. Küste, Norderney 38, 1-97.

Nicholls, D.J., Tubbs, C.R. \& Haynes, F.N., 1981. The effects of green algal mats on intertidal macrobenthic communities and their predators. - Kieler Meeresforsch., Sonderh. 5, 511-520.

Nienburg, W., 1927. Der Königshafen bei List auf Sylt. - Wiss. Meeresunters. Kiel 20, 146-196.

Obert, B. \& Michaelis, H., 1991. History and ecology of the mussel beds (Mytilus edulis L.) in the catchment area of a Wadden Sea tidal inlet. In: Estuaries and coasts: spatial and temporal intercomparisons. Ed. by M. Elliott \& J. Ducrotoy. Olsen \& OIsen, Fredensborg, 185-194.

Pedersen, A., 1983. The vegetation of the Wadden Sea islands in Denmark and Schleswig-Holstein. In: Ecology of the Wadden Sea. Ed. by W. Wolff. Balkema, Rotterdam, 137-165.

Philippart, C., Dijkema, K. \& Meer, J. van der, 1992. Wadden Sea seagrasses: where and why? Rep. Neth. Inst. Sea Res. 20, 177-191.

Reid, D.G., 1996. Systematics and evolution of Littorina. The Ray Society, London, $463 \mathrm{pp}$.

Reise, K., 1983. Sewage, green algal mats anchored by lugworms, and the effects on Turbellaria and small Polychaeta. - Helgoländer Meeresunters. 36, 151-162. 
Reise, K., 1985. Tidal flat ecology. Springer, Berlin Heidelberg New York, 191 pp.

Reise, K., 1994. Changing life under the tides of the Wadden Sea during the 20th century. - Ophelia, Suppl. 6, 117-125.

Reise, K. \& Siebert, I., 1994. Mass occurrence of green algae in the German Wadden Sea. - Dtsch. Hydrogr. Z., Suppl. 1, 171-180.

Reise, K., Herre, E. \& Sturm, M., 1989. Historical changes in the benthos of the Wadden Sea around the island of Sylt in the North Sea. - Helgoländer Meeresunters. 43, 417-433.

Richardson, B., Baverstock, P. \& Adams, M., 1986. Allozyme electrophoresis. - Academic Press, New York, 410pp.

Roberts, D. \& Hughes, R., 1980. Growth and reproductive rates of Littorina rudis from three contrasted shores in North Wales, U.K. - Mar. Biol. 58, 47-54.

Ross, B. \& Berry, A., 1991. Annual and lunar reproductive cycles in Littorina saxatilis (Olivi) and differences between breeding in the marine Firth of Forth and the Forth estuary. - J. Moll. Stud. 57. 347-358.

Ssymank, A. \& Dankers, N., 1996. Red list of biotopes and biotope complexes of the Wadden Sea area. - Helgoländer Meeresunters. 50, Supp., 9-37.

Swofford, D. \& Selander, R., 1981. BIOSYS-1: a FORTRAN program for the comprehensive analysis of electrophoretic data in population genetics and systematics. - J. Hered. 72, 281-283.

Wilhelmsen, U., 1998. Populationsgenetik und -ökologie von drei Littorina-Arten (Gastropoda) der Nord- und Ostseeküste. PhD thesis, University of Hamburg, 185 pp.

Wilhelmsen, U. \& Reise, K., 1994. Grazing on green algde by the periwinkle Littorina littorea in the Wadden Sea. - Helgoländer Meeresunters. 48, 233-242.

Williams, G., 1996. Seasonal variation in a low shore Fucus serratus (Fucales, Phaeophyta) population and its epiphytic fauna. - Hydrobiologia 326/327, 191-197.

Wohlenberg, E., 1937. Die Wattenmeer-Lebensgemeinschaften im Königshafen von Sylt. - Helgoländer Wiss. Meeresunters. 1, 1-92.

Wolff, W.J., 1992a. The end of tradition: 1000 years of embankment and reclamation of wetlands in the Netherlands. - Ambio 21, 287-291.

Wolff, W.J., 1992b. Ecological developments in the Wadden Sed until 1990. - Publ. Ser. Neth. Inst. Sea Res. 20, 23-32. 